\title{
The Image of an Addressee in Translational Discourse: Exemplified by the Texts Translated From Slovenian Language
}

\author{
Irina Shchukina \\ Perm State National Research University, Perm, Russia
}

\begin{abstract}
Translational discourse requires at least three participants, therefore it is suggested to consider the universal model of the picture of the world, according to which it is much easier for a translator to combine the pictures of the world of an addressee and an author. An addressee is a mental image existing in the mind of an addresser during the creative process. Having defined its parameters, a translator has an opportunity to deliver the thought of an addresser to an addressee as accurately as possible and to select the means of expression that are clear to an addressee. The type of an addressee correlates with "the relation to the new".
\end{abstract}

Keywords: cognitive linguistics, target text, the language picture of the world, discourse, addresser, addressee, the levels of the structure of the language world picture

\section{Introduction}

The paper deals with the mechanism of recreating an addressee's image which exists in the (sub)consciousness of the author of a literary work while text creating and of selecting linguistic means aimed at the actualization of a particular segment of reality connection performed by a translator. We believe that resolving this issue is fairly significant for translation during the selection of lexical and syntactical means. The mindset - to translate a text to make it clear for everyone - impoverishes artistic value of a literary work, reduces the range of opportunities, and redirects the addressness of a text. Translational discourse presupposes multi-vector nonlinear connection "author-text-translator-reader" which can be represented with the following scheme (see Figure 1):

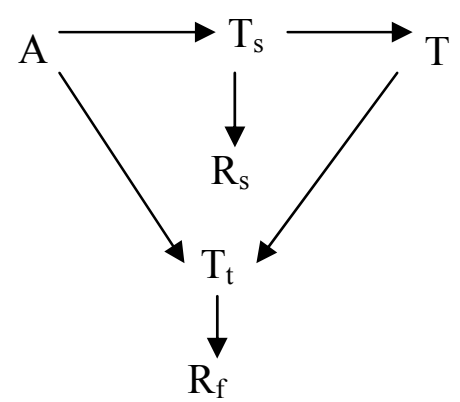

Figure 1. The model of interaction between author and reader (addresser-addressee) in translational discourse. 
Where $\mathrm{A}$ is an author, $\mathrm{T}_{\mathrm{s}}-\mathrm{a}$ source text, $\mathrm{R}_{\mathrm{s}}-\mathrm{a}$ reader of a source text, $\mathrm{T}-\mathrm{a}$ translator, $\mathrm{T}_{\mathrm{t}}-\mathrm{a}$ target text, $\mathrm{R}_{\mathrm{f}}-\mathrm{a}$ foreign reader.

We suppose that the set of assumptions of an addressee's personality that the author has correlates fairly with the structure of the picture of the world which most often is mutual for them (which, by the way, predetermines trusting mode of a text), and therefore can easily be singled out in a literary text. It is caused by the fact that the mechanism of forming the image of an addressee in author's consciousness presupposes appealing to different components of the picture of the world as long as personality or a literary image is the set of connections with reality. Considering this set in the aspect of the structure of the world picture enables us to form a paradigm of relations "addressee-addresser" and to define a translator's position in this paradigm. The opposition "our - their" which is intended to be the basis of primary conflict in a work of literature functions in short prose in a special way - most often such opposition appears within an individual as confrontation of two principles known from the antique tragedy. A translator should often decide who is our and who is their in a character's and author's consciousness, and who is their in a foreign audience.

The work has been carried out with the cognitive-stylistic analysis also comprising comparative method.

Discourse is understood in the article as the set of actualized connections of consciousness with reality, it is dynamic and being a potential base for creating a text - its final static result and supreme manifestation of discourse. It is a text in particular where actualized links between an addressee, an author of a text, and the world become apparent. The situation with the translated text is even more complicated: The connection of a reading person with an author's world and their text becomes actualized through another set of connections: the ones of a translator with an author's text, their intentions and the vector of addressness, i.e., the connection with a potential reader whom a translator chooses willingly or not. It is translating from one language to another that brings up the problem of an addressee since exactly the addressness of a text predetermines precisely, as we have already mentioned, both the tone of a literary work created on the basis of a source text and the choice of means of expression.

The task performed by translators from Slovenian to Russian language is made more complicated by the fact that their audience is not only not homogeneous, but disastrously heterogeneous. In the article "The upper and lower parts of Russian culture: The ethnic basis of Russian culture", Trubetzkoy (2007) talks about the co-existence of two obligatory parts of national culture within the same society:

Any differentiated culture comprises inevitably two obligatory parts which could be called figuratively the upper and the lower parts of the construction of this culture. By "the lower part" we mean the collection of cultural values that meet the needs of most large strata of the national whole, the so-called masses. Since these values are created by these masses themselves, they are relatively elementary and do not bear the deep imprint of individual creativity. When some values penetrate into the lower parts from the upper ones, they inevitably become slightly depersonalized and simplified as because of this migration they adapt to the general context of other values of exceptionally lower origin. (p. 178)

It should be noted that, due to the long period of forming the "whole" nation, this gap between the upper and lower parts of Slovenian culture is less apparent, also, perhaps, because the nation of the Slovenes is not numerous. But the difference in Russian culture is very substantial. In contrast to the lower:

The values of "the upper collection" are created either by the dominant parts of the national whole or for these parts, 
and always meet more sophisticated needs, more demanding tastes. As a result, they are always relatively more difficult and less elementary than the values of the lower collection. (Trubetzkoy, 2007, p. 179)

Does it follow from the above-said that the upper and lower parts of Russian culture have absolutely contrary values? Is it possible to oppose them?

\section{The Universal Structure of the Picture of the World ${ }^{1}$ of Russians and Slovenians}

The very distinction between "the upper" and "the lower" parts of culture suggests the idea of existence of some construct that reflects the state of a national world picture. Let us imagine that the picture of the world has a clear structure. Its foundation includes basic understanding of environment, typical of all representatives of any national world picture. The set of a person's relations with reality presupposes the existence of an important component - their physiological parameters:

Concrete human (private-human and common-human) [emphasis added-I. Sch.] personality is not solely a mental phenomenon. A person has both spirit and flesh and is revealed not only in the spiritual, but also in the sphere of the flesh... The synthetic study aimed at two aspects of the same personality as the psychophysical whole at once is possible too. Moreover, a person actually exists in a particular physical environment, and relations established between this environment and person are really close. (Trubetzkoy, 2007, p. 154)

The degree of difficulty of the task that translators face becomes clear during structuring the picture of the world.

\section{Universal Structure of a National Picture of the World}

Having classified people as representatives of nature, we note that they are set apart from inanimate nature by characteristics common with all animals: procreation, the law of self-preservation, and the desire for pleasure. What distinguishes a human being from animals is the attitude to fire, conscious attitude to work, and the availability of the instrument of storage and reproduction of information about the world accumulated by this collective (language). These are two general human levels (see Figure 2).

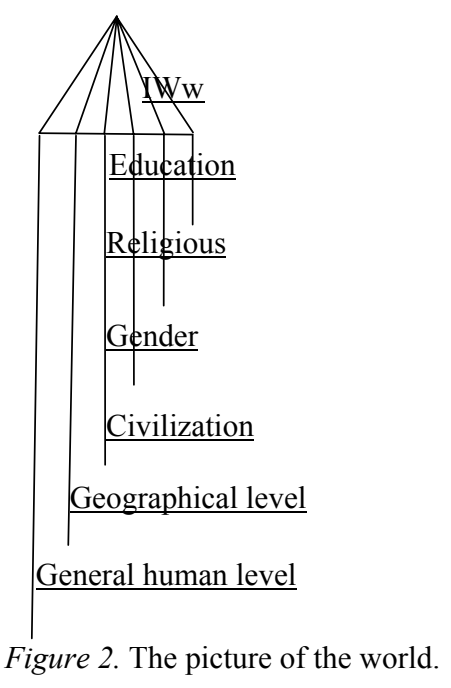

${ }^{1}$ Shchukina (2009), pp. 386-389; Shchukina (2011), pp. 6-27. 
Geographical level states the dependence of a person's worldview on a place of living. People have got their own way of looking at the world and of perceiving it depending on their habitats - in the mountains, near the sea, in the vast steppe, and in the forest area. Here we mean not only relief, but also a climate zone where people live.

Obviously it is important to state the peculiarity of this level of the world perception by the consciousness of the Slovenians in comparison with the Russians. Russia and its vast distances provide its residents with more traditional world-outlook. A person either lives in a forest, or in a steppe, or in the mountains, or near the sea. That is why everything in another country (see stranger) even at the verbal level is strange, unusual, causing bewilderment and therefore condemnation Russian consciousness (Fasmer, 1987) ${ }^{2}$. It is all absolutely different with the Slovenes, although, opposing themselves to others during the search for self-identity, they fall into one of the traps of the one's own-other's issue too (Shlibar, 2004, pp. 164-174). The moderate-sized territory of this country has a lot of climate zones, and the sea, the mountains, and the forest have all mixed up in the minds of Slovenian citizens. What is more, the local dialects, that make the young people smile, are not taken as something marginal, as evidenced by the overall love for the film "Petelinji zajtrk" by Marka Naberšnik, where characters speak the dialect of Prekmurje which is clear to a person from Ljubljana as much as it is clear to a foreigner who has learned literary Slovenian.

In the XIX century Morgan (1935) and Engels (1986) defined the term "civilization" as the stage of development of human society, which came after savagery and barbarism, and was characterized by the order of the social system, the emergence of classes, state, and private property. According to Toynbee (2001), who wrote about local civilizations as various cultural and historical systems and determined them as dynamic formations of evolutionary type, let us name a few civilizations coexisting in the modern world, such as European (Europe, North America, Australia, Asia partly), Far Eastern (Japan, China, Vietnam, Thailand, etc.), American Indian (Venezuela, Chile, Mexico, etc.), Indian (India, Bangladesh, Pakistan, partly some of African states) and others. This approach allows us to talk about one more level-the level of civilization.

Please note that Slovenia and Russia belong to the same European civilization. It is not accidental that many idioms, most often derived from Latin, have the same meaning in Russian and Slovenian languages, and are common to the Slovenes and Russians: "китайские церемонии"- "kitajski ceremonial” (standing on ceremony), “давай без церемоний”-“Ne uganjaj ceremonij” (let's avoid ceremonies), “вечный город”-“Večno mesto" (the Eternal City), “все дороги ведут в Рим”-“Vse poti vodijo v Rim” (all roads lead to Rome). The European civilization has also got the names of scholars and historical figures in its scientific and political archives unknown to representatives of other civilizations ${ }^{3}$.

Certainly one of the most significant components of the picture of the world is religious worldview. Despite the fact that the Russians and Slovenes are both Christians, the denominations that are dominant in Russia and Slovenia have different approaches to the role of a human being in the world. The Catholic Slovenians believe that a fishing rod should be given to a needy person so that they could catch a fish, while the Orthodox Russians are sure that the responsibility for their lives is as follows: On God, the president, the governor, the deputy, the

\footnotetext{
2 Translator's note. The Russian word “страна” (country) which derives etymologically from “чужестранец” (foreigner, stranger) has got the same root as the word "странное" (strange).

${ }^{3}$ For example, the theorem on the equality of the square of the hypotenuse to the sum of the squares of two other sides is associated by Europeans with Pythagoras, but not in the Far East where this theorem had been proved by an unknown Chinese mathematician two thousand years before Pythagoras.
} 
chief, and therefore they should solve the "fishing" problem. This idea may be illustrated by the recent events in Orthodox Greece where citizens believed that the EU was obliged to provide them with a decent standard of living. On the contrary, the Catholic Slovenes had been participating in demonstrations for several months until they achieved the resignation of the corrupt minister, from their point of view. This state of affairs has obviously been caused by the Eastern Christianity lack of interest in the analysis of not only domestic, but also existential issues, faith issues, and simply theological problems. This is what Zhivov (2013) writes on this subject in his recent interview:

The main thing that the Rus' had not inherited from Byzantium was Byzantine secular culture which, generally speaking, was the continuation of the Late Antique culture... In order to understand patristic texts, it was necessary to speak the language of Greek philosophy and to have certain philosophical knowledge that the Byzantine school taught, but which the Eastern Slavs did not have ${ }^{4}$.

On the contrary,

Throughout the early middle ages, the Western Church had a vested interest not only in missionary work, but also in educating barbarians who attacked it. The Church sought to convert at least some of those barbarians to the Romans. That created canals, and a thin stream of Christian scholarship was handed down from generation to generation, from Antiquity to the middle ages 5 .

Gender stereotypes as sociocultural constructs "act as cognitive schemes that govern the processes of processing of incoming information so that we begin to perceive and interpret it according to our ideas of gender" (Rezvushkina, 2002, p. 187). Society is involved in the maintenance or destruction (the same-sex marriages law) of the prevailing stereotypes. Women in Russia (which has been developing by leaps and bounds through revolutions and having a longstanding desire to jump the gun) who used to strove for freedom and equality tend to give up their gains now, which is also typical of a national picture of the world: As we know, "ideas become obsolete quickly in Russian society" (Prokhorov \& Sternin, 2007, p. 115). The social role of a woman in Slovenia is more traditional than in Russia despite the fact that the Prime Minister Janez Janša has been replaced by Alenka Bratušek (Ule, 2011a, pp. 112-123; 2011b, pp. 75-86) . $^{6}$

Sociolinguists pay special attention to the stratum of "education" in their studies. The Austrian Empress Maria Theresa established compulsory primary education for her nationals almost 300 years ago. Eighty years ago the Russians "were obsessed with total literacy" too. These figures might have no special meaning for the course of human development, but they are fairly significant for forming a national picture of the world. In the early 20th century Anton Ashkerts wrote: "naše ljudstvo je v kulturnem razvoju in splošni omiki najmanj za tristo let pred ruskim" (Aškerc, 1903, p. 728) ${ }^{7}$. A hundred years has passed and a lot has changed, but a national picture of the world changes more slowly. Today the Slovenes say proudly about themselves that every second person has got higher education, while in Russia even a complete secondary education is not compulsory. But a paradox

\footnotetext{
${ }_{5}^{4}$ It's not Byzantium's fault (Private correspondent). 19. 04. 2013.

5 It's not Byzantium's fault (Private correspondent). 19. 04. 2013.

6 "There is a constantly updated tradition of gender discrimination while applying for different education directions, as well as men-orientation of science and technology education. It is evident from the content of textbooks, the choice of examples, methods of teaching, and general atmosphere of a classroom".

${ }^{7}$ Our (Slovenian) people have gone ahead of the Russian people in the cultural development and education for three hundred years.
} 
should be noted. Apparently it is the gap between "the lower" and "the upper" parts of culture that has enabled Russians to create masterpieces of great literature, which the more educated Slovenian people have not got yet.

The top of the notional structure of the world picture is individual worldview. It is important to note that the previous levels have already done their job and formed basic world-image in an individual's consciousness indifferently to any individual approach. While considering an individual picture of the world, in addition to the listed parameters, we should also remember the physiology of a person, their temperament, what kind of family they grew up, what talents they have, and how they have been applied. This level includes the entire range of relationships with the world that differentiates people from each other.

Due to the peculiar historical development Russians were divided into two unequal parts that Trubetzkoy (2007) classified notionally as "the upper" and "lower" parts of Russian culture. They are people with diametrically opposed attitudes to the world, and therefore the addressees of a literary work should be presented by two different types (Lurie, 2002). It is not accidental that inconsistency, unpredictability, and the polarity of opinions are thought to be the Russian's characteristics. We think that the criteria for a particular level of culture could be the attitude to something new-knowledge, place, culture, person, and viewpoint, i.e., something that has been absent in the worldview or has not been discovered. Usually everything new is interesting for the representative of "the upper part" of Russian culture, they learn and develop it enthusiastically, enriching their own vision of the world (actually this is the reason why we have got that great literature that flawlessly combines the European literary psychologism and the eastern pursuit of the ideal), they are constantly on the way of self-improvement. Let us define it as type A. Type B is often a representative of the "lower parts" of the culture, who was educated as needed (even has got higher education), who is convinced that the best events have already happened and will never happen again, whom everything new irritates and causes aggression, and who seeks to preserve traditions (see Figure 3).

adressee:

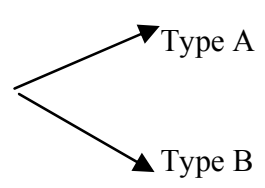

Interested in everything new. Tries to improve their own life and personality.

Everything new is under suspect, it irritates them. Tries to preserve traditions.

Figure 3. Types of an addressee of an artwork.

Despite the fact that Lurie's observation confirms Trubetzkoy's idea of the existence of two different parts of Russian culture, it is impossible to oppose two pictures of the world since, as we can see, the "upper" picture of the world includes all elements typical of the lower part which enabled translators of the previous decades to avoid the hard work of guessing who a literary work was addressed to. One could appeal to the basic components of a national picture of the world - and the problem was solved. However, if we examine the structure of the Slovenian picture of the world, we can determine easily that a Slovenian author is likely to write for a reader who in Russian environment is an addressee of type A, and therefore, defining an addressee is a much more difficult task than it seemed before.

\section{Translation and the Structure of the Picture of the World}

We will try to recreate the personality of an addressee using contextual analysis with the help of the picture of the world structure in a little novella "The Crab" by the Slovenian author Andrej Brvar (2004) (see Table 1). 
Table 1

The Correspondence of Parts of the Source and Translated Texts

\begin{tabular}{|c|c|c|}
\hline Isente.-/nce & Andrej Brvar. Rakovica. & Andrej Brvar \\
\hline 1 & $\begin{array}{l}\text { Z enakomernimi zamahi plavutk sem se počasi, kot bi } \\
\text { se zbujal iz sanj, dvigal ob strmi skalnati obali, skoz } \\
\text { zelenkasto modrino, ki je počasi zmanjševala pritisk, } \\
\text { vse bolj nemirna, vse bolj svetla, vse bolj topla. }\end{array}$ & $\begin{array}{l}\text { It was like with even flaps of fins I was rising slowly from the } \\
\text { sleep, climbing the steepness of the rocky shore, through the } \\
\text { greenish blue that was slowly lessening the pressure, more } \\
\text { and more restless, lighter and lighter, warmer and warmer. }\end{array}$ \\
\hline 2 & Malo pod živosrebrno bleščavo sem jo zagledal. & I saw it under a slightly mercurial shine. \\
\hline 3 & Imeti jo, imeti! & Get it, get it! \\
\hline 4 & Me je popadla nenadna, neprimagliva želja. & A sudden, irresistible desire seized me. \\
\hline 5 & $\begin{array}{l}\text { Počivala je pred razpoko, sredi ovalnego stekla } \\
\text { maske, nenavadno velika v svojem temno zelenem, } \\
\text { bolj širokem kot dolgem košu, in si s škarjami trebila } \\
\text { zobce. }\end{array}$ & $\begin{array}{l}\text { He was resting in front of a crevice, through the oval glass } \\
\text { mask, excessively large in his dark-green rather wider than } \\
\text { longer duct, and was cleaning his barbs with his pincers. }\end{array}$ \\
\hline 6 & Imeti jo, imeti! & Get it, get it! \\
\hline 7 & Pokazati jo drugim! & Show it to others! \\
\hline 8 & $\begin{array}{l}\text { Zgrabil sem skalnati okružek, začel sem tolči po trdi, } \\
\text { spredaj malo zaokroženi lupine, opletala je s } \\
\text { škarjami, ih iztezala v obrambi, razpirala klešče, } \\
\text { skušala je zadenjsko zaplavati v razpoko, se rešiti, } \\
\text { zbežati, ampak udarci so jo zmeraj znova z } \\
\text { nezmanjšanim besom dohitevali, dokler se ni iz } \\
\text { zmede muljastega oblačka skotalila v globino, v } \\
\text { oblačku pa so se vrtinčile odtrgane hodilke in desne, } \\
\text { močnejše škarje, in klešče na njihovem koncu so se še } \\
\text { zmeraj odpirale in zapirale, odpirale in zapirale... }\end{array}$ & $\begin{array}{l}\text { I grabbed a rock debris and began to hammer the firm testa, } \\
\text { slightly rounded ahead, he swayed his pincers, stretched them } \\
\text { out for defense, moved them apart, he moved back trying to } \\
\text { swim into the crevice, trying to escape, to run away, but every } \\
\text { time my stabs that I delivered with an increasing frenzy } \\
\text { overtook him, until in the disconcert of the little cloud of silt } \\
\text { he slid down into the deep, and there were torn away feet, } \\
\text { turning, and the strong right pincer left in the muddy water, } \\
\text { and the scissors at the edge of the pincer still convulsively } \\
\text { opened and shut, opened and shut... }\end{array}$ \\
\hline 9 & Tistega dne si nisem upal več v morje. & \\
\hline 10 & $\begin{array}{l}\text { Veter je vse bolj naraščal in valovi so vse bolj bučali, } \\
\text { vse bolj renčali, renčali in razkrivali dolge, koničaste, } \\
\text { bele zobe. }\end{array}$ & $\begin{array}{l}\text { The wind was growing more and more, and the billows were } \\
\text { stooping more and more, roaring more, growling, baring long } \\
\text { cone-shaped monstrous white teeth. }\end{array}$ \\
\hline 11 & & I have never dared to enter the sea again since that day. \\
\hline
\end{tabular}

The first sentence is addressed to a person living near the sea or with diving experience. The details of rising from the deep prompt a reader to feel the sensation of such rising again. “... with even flaps; I was rising slowly from the sleep; climbing; through the greenish blue; slowly lessening the pressure, more and more restless, lighter and lighter, warmer and warmer" (Brvar, 2004, p. 24). At the same time we realize that this person is not on tour. $\mathrm{He}$ is not admired by what he sees - it is his natural environment. He describes only his state which is certainly very pleasant and close to the state after visiting a bathhouse of Russian people. The character is tired of pressure and thus is a little bit slow waiting for longed-for rest. Everything around him changes slowly: was rising slowly, slowly lessening the pressure. The refrain repetition of the forms of comparative degree (more and more restless, lighter and lighter, warmer and warmer) also emphasizes the slowness of the changes and the character's absorption into his feelings rather than contemplating the environment: Now, that is - the warms stones on the shore, the opportunity to luxuriate and relax under the southern sun. It will be clear from the following passage which shows that the character tries to get the object of hunting deliberately. This fragment appeals to the segment of consciousness formed by the geographical level of the picture of the world.

The "mercurial shine" in the second sentence (Malo pod živosrebrno bleščavo sem jo zagledal) demonstrates theatre device which forms the proper stage behaviour of actors in Stanislavski's system: see $\rightarrow$ evaluate $\rightarrow$ decide $\rightarrow$ answer. An object should stand out from others somehow to be seen, and in this case the 
mercurial shine helps to do so. The impulse to careful examination and subsequent evaluation is the following - the object is unusually large, it would be good to show it to others (to boast of). The decision is to get it at any price. This device of text developing refers to the level of education or an individual picture of the world. The author believes that his addressee will appreciate such almost cinematic chain of actions that is necessary for him to create tension in the short prose closeness which is comparable only to the tension of Hemingway's (2011) novel The Old Man and the Sea or a hunting scene in War and Peace by Leo Tolstoy (1991).

The third sentence is the immediate decision-Imeti jo, imeti! Let us note that the Slovenian word for "crab" - "rakovica" - is of feminine gender. And this sentence contains the feeling which has been already formed at the two levels of the picture of the world structure: the biological - the character is a hunting animal, a predator-and the gender level as in Russian it would sound in a sexual way-uметь её, иметь! (to have her, have her). The word "иметь" (have) ${ }^{8}$ and the feminine gender of the word denoting the object of desire refer to heterosexual relationships. The Russian version is “достать его, достать!” (get it, get it!). The translator, who obviously is a woman, has paid attention to the discrepancy between grammatical gender in Russian and Slovenian languages and changed the sexual connotation of the sentence into a hint of the character's passion for hunting. But since such passion is typical of men rather than women, the text suggests that the image is developed not only at the biological level, but also the gender one.

If we pay our attention to the gender stereotypes, we will see that a woman, wife, and mother who forms the emotional beginning of her children, is not very emotional as a Christian ideal. Such phrases as "unrestrained passion and irresistible desire" describe traditionally the behaviour of a non-Christian woman of exceptional type, for example, Carmen, whose feeling do not last long. It is another thing when it comes to men. Phrases such as "he had a secret passion", "hunting was his passion" do not surprise anyone. That is why the forth sentence which contains the phrase "a sudden", "irresistible desire" is certainly addressed to a man, i.e., is formed by the consciousness at the gender level. The seventh sentence is similar with the forth. Here the triumphant finale of possessing a trophy is imagined as "showing it to others", i.e., being a winner, being victorious, which also reveals the desire that has been called "irresistible" in the previous passage. Competitiveness is more typical of men than women. That is why the text primarily appeals to them and thus is gender again.

The sentence describing the hunting is the longest and the most intense, as they say, in one breath. It is understandable as in one sentence the main conflict of the text arises, develops, and settles down. Let us compare this sentence with the passage describing the hunting in Tolstoy's "War and Peace" (see Table 2).

The tension of the texts is created by both authors with a big number of verbs and gerunds describing rash actions. See Tolstoy: закричал (came [a third voice]), вытягиваясь и выгибая (straining and curving), сравнялся (caught up), выдвинулся (pushed ahead), наддал (put on speed), сбил (knocked it off), наддал (put on speed), утопая (sinking), пачкая (muddying), покатился (rolled over), окружила (surrounded). There are 74 words in the fragment of Russian text, and 16 per cent of them (12 words) are verbs and gerunds. Four words of them mean the high-intensity activity or have connotations (наддал (put on speed), сбил (knocked it off), наддал (put on speed), покатился (rolled over).

Brvar: схватил (grabbed), начал долбить (began to hammer), размахивал (swayed), вытягивал

8 The phrase that is translated into Russian as "to love" sounds as "rad imeti" in Slovenian. 
(stretched out), раздвигал (moved apart), пробовал двигаясь (moved back trying), запльтьь (swim), сnастись (escape), сбежать (run away), наносил (delivered), настигали (overtook), скатился (slid down), остались (were left), закрывались и раскрывались, закрьввались и раскрывались (opened and shut, opened and shut). There are 79 words in the passage of the Slovenian text and its Russian version, and 21.5\% of them (17 words) are verbs and gerunds. Here the high intensity of actions is created by five verbs: схватил (grabbed), долбить (hammer), размахивал (swayed), сбежать (run away), наносил (delivered), настигали (overtook).

Table 2

Ways of Explication of Action in Tolstoy's and Brvar's Passages

\begin{tabular}{|c|c|}
\hline The hunting episode in Tolstoy's "War and Peace" & Andrej Brvar-"The Crab" \\
\hline $\begin{array}{l}\text { "Rugay, Rugayushka! That's it, come on!" came a third } \\
\text { voice just then, and "Uncle's" red borzoi, straining and } \\
\text { curving its back, caught up with the two foremost borzois, } \\
\text { pushed ahead of them regardless of the terrible strain, put } \\
\text { on speed close to the hare, knocked it off the balk onto the } \\
\text { ryefield, again put on speed still more viciously, sinking to } \\
\text { his knees in the muddy field, and all one could see was } \\
\text { how, muddying his back, he rolled over with the hare. A }\end{array}$ & $\begin{array}{l}\text { I grabbed a rock debris and began to hammer the firm testa, slightly } \\
\text { rounded ahead, he swayed his pincers, stretched them out for defense, } \\
\text { moved them apart, he moved back trying to swim into the crevice, } \\
\text { trying to escape, to run away, but every time my stabs that I delivered } \\
\text { with an increasing frenzy overtook him, until in the disconcert of the } \\
\text { little cloud of silt he slid down into the deep, and there were torn away } \\
\text { feet, turning, and the strong right pincer left in the muddy water, and the } \\
\text { scissors at the edge of the pincer still convulsively opened and shut, } \\
\text { opened and shut }{ }^{10} \text {... }\end{array}$ \\
\hline
\end{tabular}

As we can see, Brvar's text is more intense than Tolstoy's, although it contains only five more verbs and gerunds. This tension is apparently achieved not only by using a bigger amount of verbs (the percentage difference is more illustrative: $21.5 \%$ vs. $16 \%$ ), but also by using one more device. Brvar makes us feel sympathy both towards the prey (the victim) and the hunter, opposing the animal nature and the spiritual in the mind of an addressee. He refers us to the animal state of our consciousness writing about the hunter: (A sudden, irresistible desire seized me-4), grabbed a rock debris, with an increasing frenzy. (Tolstoy stops at this animal state describing though not a man-hunter, but a hunting dog). We understand him as animals. Everyone has had such irresistible desire at least once in their life, so the verbs of actions aimed at satisfying this desire (grabbed, began to hammer, delivered, overtook) are clear to us. But the author tells us about the victim appealing to our human, even Christian capacity for compassion: for defense, swim into the crevice, escape, run away, the disconcert, torn away feet ... and the strong right pincer, convulsively opened and shut, opened and shut. This life rhythm of the lifeless creature puts the character back into a human state capable of compassion. We know that religion teaches us to empathize and help the needy. In this fragment the author certainly appeals to the opposed levels of the picture of the world-biological and religious.

This sentence also demonstrates the peculiarities of language that are known only to the residents of sea territories or biologists. Both of the Slovenian words "škarje" and "klešče" presented in the source text (but

\footnotetext{
9 Translated by Louise and Aylmer Maude. Ругай! Ругаюшка! Чистое дело марш! - закричал в это время еще новый голос, и Ругай, красный горбатый кобель дядюшки, вытягиваясь и выгибая спину, сравнялся с первыми двумя собаками, выдвинулся из-за них, наддал со страшным самоотвержением уже над самым зайцем, сбил его с рубежа на зеленя, еще злей наддал другой раз по грязным зеленям, утопая по колена, и только видно было, как он кубарем, пачкая спину в грязь, покатился с зайцем. Звезда собак окружила его....

10 Я схватил обломок скалы, начал долбить по твердому, впереди немного закругленному панцирю, он размахивал клешнями, вытягивал их в защите, раздвигал их, пытался, двигаясь назад, заплыть в расщелину, спасти сь, сбежать, но каждый раз мои удары, которые я наносил с усиливающимся остервенением, настигали его, пока он в замешательстве в илистом облачке не скатился в глубину, в мутной воде остались вертящиеся оторванные ноги и правая мощная клешня, и ножницы на ее конце все еще судорожно закрывались и раскрывались, закрывались и раскрывались....
} 
translated into Russian and English with one word-“клешня" and "pincer", respectively) denote different parts of prehensile limbs of crab. The definig dictionary of Slovenian language "Slovenski pravopis" (Baez, 1962) published by Slovenska akademija znanosti in umetnosti determines the word "skarje" as "rakove škarje", while "klešče" is explained only as a tool and a gorge between rocks. This allows us to suppose that the word klešče is a localism not presented in literary Slovenian. It means that the author believes that readers know this word, i.e., they live near the sea and know localisms denoting parts of crabs' pincers. This author's move takes us back to the geographical level of consciousness of an addressee.

The two last sentences could certainly be attributed to the religious level. The sentence "Tistega dne si nisem upal več v morje" (I have never dared to enter the sea again since that day) is not the last one in the source text, but it contains the author's reflection over what has been done. So what has happened? The hunter has won his prey. It is true that he has had to hurt the animal, but why would the hunter avoid coming to the place of the battle or feel like a criminal? Is it possible that the hunter is disappointed because it is not that pleasant to show the damaged trophy? No, he is not a hunter now, but a killer, and the author reveals his repentance with this phrase and hopes that an addressee understands his intention. It means that this statement should refer us to the religious level of the picture of the world which is responsible for developing moral foundations of an individual and society. The author's intention is almost explicated. The text will not be understood unless an addressee has got a set of moral rules. The author emphasises the religious aspect: the whole nature resents-Veter je vse bolj naraščal in valovi so vse bolj bučali, vse bolj renčali, renčali in razkrivali dolge, koničaste, bele zobe. This sentence shows the author's and the character's attitude to the act of hunting-killing. The nature rejects him, and this is a punishment for the killing.

The author actualizes the character's connections with the external world by creating a literary image. By putting it into the centre of discourse, he tries to establish such connections with an addressee too and to arouse the same feelings, desires, and memories of their experiences. He appeals to the different levels of an addressee's consciousness: biological (a hunting man, a predator), gender (the excitement of the winner, with a hint of sexual desire), religious (the repentance of the killing, supported with the anger of the nature), and geographical. The only detail that could be attributed to the level of civilization is probably the diving mask that the character wears if we take into account that young outcasts dive looking for pearls in the Indian Ocean still without aqualungs. The device of text developing (close to cinematography) which indicates the humanities education or high standard of living (an individual picture of the world) should be attributed to the level of education. It is interesting that most often the author appeals to the gender level (four sentences), to the geographical level (three sentences), three sentences too - to the religious, two - to the biological, one - the level of education, one - the level of civilization. Our analysis enables us to determine quite accurately the supposed personality of an addressee: It is a man, the sanguine-choleric person, who lives near the sea, has higher (possibly humanities or biology) education, and is a probable lover of intellectual entertainment. However, we have not examined the individual picture of the world that could have edited this image, and as for the inner conflict, it has been represented so masterfully that it could expand the circle of addressees. 


\section{Conclusions}

In summary, the set of assumptions of an addressee's personality, that an author has, correlates fairly with the structure of the world picture which most often is mutual for them (unless the genre of a literary work presupposes the opposite), and can easily be singled out in a literary text.

(1) The mechanism of forming an addressee's image in an author's consciousness presupposes appealing to different components of the set of connections with reality.

(2) The opposition "one's own - other's" which usually becomes the basis of main conflict in a work of literature functions in short prose in a special way - as confrontation of two principles within an individual (the animal nature and the spiritual, duty and love, etc.).

(3) By simplifying a text, which allows to expand the range of addressees, a translator impoverishes the literary world, making the set of feelings more standard than an author intended (rakovica-crab, škarje, klešče-pincer).

(4) By expanding the range of addressees, the translator readdresses the text to representatives of all culture levels, like popular Russian writers have been doing (Valentin Pikul, Alexandra Marinina, Daria Doncova, etc.).

(5) The issues of whether it meets the demands of representatives of the upper level of culture or not and what it gives to representatives of the lower are the issues beyond the scope of our research.

\section{References}

Aškerc, A. (1903). Dva izleta na Rusko; crtice s potovanja (Two trips to Russia; Traveler's notes). Lubljana: Ljubljanski zvon (Ljubljana bell).

Baez, A., \& Kolarich, R., et al. (Eds.). (1962). Slovenian orthography (The edition of The Slovenian Academy of Sciences and Arts). Ljubljana: State Publishing House of Slovenia.

Brvar, A. (2004). Naplavine (The Surf). Ljubljana: Beletrina.

Engels, F. (1986). The origin of the family, private property and the state (Vol. 3) (K. Marx, \& F. Engels Selected Works). Moscow: Politizdat.

Fasmer, M. (1987). Etymological dictionary of Russian language (Vol. 3). Moscow: Progress.

Hemingway, E. (2011). The old man and the sea. Moscow: Astrel.

Kubryakova, E. S. (2000). On the notions of discourse and discourse analysis in modern linguistics. Discourse, Speech, Speech Behaviour: Functional and Structural Aspects (Collection of reviews). Moscow.

Lurie S. V. (2002). Searching for Russian national character. Retrieved from http://www.strana-oz.ru/2002/3/v-poiskah-russkogo-nacionalnogo-haraktera

Mechkovskaya, N. B. (2000). Social linguistics. Moscow: Grand.

Morgan, L. G. (1935). Ancient society, or researches in the lines of human progress from savagery through barbarism to civilization. Leningrad: The Institute of the Peoples of the North CEC of USSR.

Prokhorov, Y. E., \& Sternin, I. A. (2007). The Russians: Communicative behavior. Moscow: Nauka.

Ratbil, T. B. (2006). The human factor in language: Linguistic pragmatics and the speech act theory. Nizhny Novgorod: Publishing house of the University of Nizhny Novgorod.

Rezvushkina, T. (2002). The use of the semantic differential in the study of gender stereotypes. Gender Studies in Central Asia (pp. 187-193). Almaty: Institute of Development of Kazakhstan.

Ščukina, I. (2011). Ruska televizija leta 2010 skozi prizmo nacionalna identitete (The Russian television in 2010, through the prism of national identity). Ars \& Humanitas, 5(1), 40-55.

Sedov, K. F. (2009). Linguistics. Speech studies. Genre studies. Genres of Speech. No. 6, 32. Saratov: Publishing House of State University of Saratov.

Shchukina, I. (2011). Russian television through the prism of the national picture of the world. Journalism and Russian Speech Culture (pp. 6-27). No. 4. Moscow: Publishing house of Moscow State University. 
Shchukina, I. K. (2009). Vprašanju o nacionalni sliki sveta (On the national picture of the world). Zbornik 12 mednarodne multikonference "informa-cijska družba"-IS (The proceedings of The 12th International Multiconference "Information Society”). Ljubljana, Slovenia: Institut Jožef Stefan (Lubljana: the Institute of Joseph Stefan), 386-389.

Shlibar, N. (2004). Blind spots in the perception of another. Philological Notes, 3, Perm-Ljubljana, 164-174.

Tolstoy, L. (1991). War and peace (Vol. 2, p. 196). Moscow: Prosveshchenie.

Toynbee, A. (2001). A study of history. Moscow: Rolf.

Trubetzkoy, N. S. (2007). The legacy of Genghis Khan. Moscow: Eksmo.

Ule, M. (2011a). The changes of students position in modern European society. Perm University Bulletin. Philosophy. Psychology. Sociology, 2(6), 112-123.

Ule, M. (2011b). The changes of the process of growing up and gender stereotypes. Perm University Bulletin. Philosophy. Psychology. Sociology, 4(8), 75-86.

Zhivov, V. M. (2013). It's not Byzantium's fault (Private correspondent). 